\title{
Using meta-ethnographic analysis to understand and represent youth's notions and experiences of learning in and out of secondary school

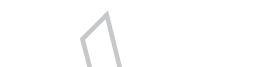

AQ2 Fernando Hernández-Hernández ${ }^{a}$ and Juana M. Sancho-Gil ${ }^{b}$ (1)

Department of Visual Ar d Design, Unit of Arts and Visual Culture, University of Barcelona, Barcelona, Spain; ${ }^{b}$ Department Teaching and Educational Management, University of Barcelona, Barcelona, Spain

\section{ABSTRACT}

In the last four years, we have been researching how five groups of young people were learning inside and outside secondary schools. The novelty of this proposal was to invite these young people to act as researchers by carrying out their own ethnographic cases. As a result we produced 10 ethnographic reports -5 prepared by students and 5 by the university research team. In this paper, we show part of the conversation between the five ethnographic reports written by us giving account of the processes and results of the studies implemented by students. This meta-ethnographic process tries to accomplish two main objectives: (a) to characterise the variety of youth' learning experiences in their mobilities and transitions in and outside schools and the ways of giving account of them in the ethnographic reports; (b) reporting own learning about the possibilities and limitations of the metaethnographic analysis.

\section{KEYWORDS}

Mobility learning; poststructuralist ethnography; learning contexts; formal and informal learning

\section{Introduction: youth transitions on their learning in and outside secondary schools}

The motivation to develop this research was to understand how young people learn in multi-sited environments and to suggest possible pedagogical alternatives to the apparent disconnection between their formal and non-formal learning practices. ${ }^{1}$ This could contribute, we expect, to reduce young people's school disaffection and the amount of students who do not continue their studies beyond compulsory education (currently in Spain $22.7 \%$, and at the EU $11 \%)^{2}$

Our initial hypothesis was that there is a gap, a disconnection (later, during this research, we realised that there is more a transition process), between what the secondary school considers as learning (mainly listening, doing exercises and reporting in exams), and how young people learn outside the school using different media and literacies (mainly spontaneously, with no regulations and with connections with their interests). To explore this hypothesis, and being in a position of offering suggestions to improve secondary education, we studied how young people learn inside and outside school, in 
communities of exchange and using different literacies and technologies. We carried out this study with them and not on them (Hernández 2011; Nind 2014) in order to better explore and understand features shaping the ways young people learn and how they perceive and experience their own learning networks and environments.

\section{Doing ethnography with young people}

This project sought to understand, through a series of five multi-sited ethnographies (Faizon 2009; Marcus 1995), that move through school and home (Denzin 1997; Troman, Jeffrey, and Walford 2005), and virtual environments (Hine 2000, 2005; Jhons, Shin-Ling, and Hall 2004), the social life of young people using and learning with multiple literacies to express and communicate themselves.

When studying young people's learning experiences in and outside school, we moved, as Milne (2006) notes, through 'the interplay between physical spaces and virtual spaces' (in Sharpe, Beethan, and de Freitas 2010, xvii). As Milne, we identified in our ethnographical research formal physical spaces (classrooms and seminar rooms), physical social spaces (playgrounds), physical transition spaces (corridors), physical private spaces (students' home) and virtual social spaces (in the case of this research, Facebook, Dropbox, Googlesite, etc.). It seems clear that for any learning activity young people 'may combine or recombine various combinations of these types of spaces' (Sharpe, Beethan, and de Freitas 2010, xviii). These spaces also shape the multi-site fields where our ethnographic research took place.

From this starting assumption, we took two theoretical frames into account. First, that learning goes beyond cognitive and pedagogical dimensions. Learning is not only what occurs in the space/time between an input (teaching) and an output (assessment). Learning is a complex matter connected with life and biographical experiences, dialogical conversations, inquiry processes, or the way the (new) unconscious operates (Mlodinow 2012). Therefore, learning embodies new and significant challenges for educational systems (Stoll, Fink, and Earl 2001).

Second, we tried to counteract the situation pointed out by Anderson and Herr (1994, 59) that 'students are everywhere in schools, and yet they are too often invisible to the adults who work there'. In our case, involving young people in the research process by giving them the possibility of developing their own ethnography required us to question our adult-centred mode of understanding the relationship with the life of a group of students and the ways in which their social worlds are moulded and influenced. This position obliged us to build a research project based on participation, collaboration and inclusion (Heath et al. 2009; Nind 2014), while using different methods to collect evidence and build the ethnographic accounts.

\section{The ethnographic research process}

The research was carried out in five secondary schools, placed in the semi-rural and the metropolitan area of Barcelona (Table 1). In each school a group of six high, medium, and low performance students in their last year of compulsory education (15-16 years old) was invited to engage in a collaborative ethnography with two university researchers, to inquire into learning in and outside school with multiple literacies and digital 
Table 1. Multi-ethnographic sites.

Schools Context (based on the interpretative ethnographic reports)

Els Alfacs Semi-rural state school (180 km south of Barcelona). Due to the popularity of the teacher presenting the project to the students, also a member of the research team, there were 11 students participating in the study. It was agreed with the school that the working sessions would be done within the setting of an extracurricular subject. Even if at the end of the school year their work was submitted and assessed as curriculum content if the form of the group research project. The working sessions were held in the Visual Education classroom with several tables arranged for group work. We were faced with the difficulty of breaking with a traditional work dynamic where the adult decides and the young people produce. What enabled a change of course was when, after a few weeks, the young people stopped asking what we wanted them to do, and began to take hold of the reins themselves. At this moment each one of them became involved in a different way and intensity, contributing diverse aspects to the project with textual, auditory, visual, and audiovisual resources, maps, and digital presentations

El Palau State school in the metropolitan area of Barcelona (25 Km West). The school grouped the students by ability. Our demand to work with a mixed ability group took to gather students attending group A (lower capacities) and group B (higher capacities). The first stage of the study was focused on interviews and observations. The youths divided into two equal groups with assigned roles. The written observations were shared among the whole group to analyse them and try to form conclusions. Students from group A took part less initially, but were more involved in individual tasks. As a result of the collaboration between members of both groups, those in group A ended up taking part more and those from group B undertaking the programmed tasks. In the second stage, the youths produced the report for project they had to present in the school. On having to do it with their class group, they had to be separated. This separation did not help either the development or the production of the final report, above all for group A students who presented a project that did not reflect the work done

Riera State school in the metropolitan area of Barcelona (13 km South). As the school had not yet decided how to undertake the final-year CSE project, we agreed with the students to meet after school. We had a sandwich together chatting about different things and later focused on the task at hand. This contributed to increasing the mutual trust and recognition. All work sessions were carried out at school, which facilitated equipment, except one which took place at the University of Barcelona. The process reflected the conditions of the context. One of the students only attended one session. He did the work enthusiastically together with his colleagues, but did not return. His presence was very intermittent in the school too. Another took part sporadically, but had an important role in the development of the presentation in the university. These two cases show that collaborative research and learning are not an answer in themselves, despite the interest and the considerable results recognised by the students. At the end of the school year the study carry out by students was satisfactorily assessed as the group research project

La Mallola State school in the metropolitan area of Barcelona (10 km West). The work undertaken by students did not form part of the final-year CSE, but had institutional recognition since it was presented in the school with the attendance of a representative of the council. They decided on their participation in the project on a voluntary basis, but the fact of not forming part of a regulated school activity, although done during class time, put them off initially. The interest aroused in them by the study topic kept them in the group, despite their ambivalence, but meant, initially, that their collaborative research work and learning was focused in the classroom sessions. After the first meetings, the need to broaden communication and collaboration beyond the confines of the school were considered, in order to share the material produced. The majority of interventions were by the two researchers from the university and three of the students. As the presentation time approached, the occasional collaboration became accumulative and all of them carried out the research tasks,

Virolai Charter school located in the upper part of Barcelona. The research was carried our during school time as it was considered as the final-year CSE group project. We met in a Sciences Lab, where the young people attended with their laptops or tablets, and we arranged the space to favour communication. From the first sessions, we tried to break with the dynamic of the adult who mainly decides and explains. We thus highlighted a step forward when we agreed with the students that they will interview and film each other explaining their learning and expressive experiences inside and outside the school. In these interviews, the young people gradually gave themselves different roles and made decisions and assumed their authorship. During the ethnographic research, the most used digital resources were a website and the documents shared online. According to the young people, the use of the website enabled them to monitor the evolution of the research and do their project since the work sessions were ordered chronologically with their corresponding significant information in a single shared space 
technologies. When we negotiated with students and schools their participation in the project, and the ethical agreements were signed, the curriculum for final-year Compulsory Secondary Education (CSE) in Catalonia included the production of a group research project. This project, on which one hour should be spent each week, was understood as 'a series of activities of discovery by the pupils regarding a subject chosen and marked out, partly by themselves, with the guidance of the teaching staff (Departament d'Educació 2010, 251). However, when students started the ethnographic studies, a provision of the Department Education turned this project into optional, so the work done by the students was not in all cases regarded as part of the curriculum. Nevertheless in all cases their work was somehow recognised and assessed by schools and was presented in a public event at the University of Barcelona. ${ }^{3}$,

The fieldwork in each site took place during the academic year 2012/2013 and entailed weekly sessions from approximately six months. During these meetings, researchers guided students' processes and trained/teach them to formulate research questions and to collect and analyse evidence (observation, documents' analyses, interviews, etc.). We tried not to impose our questions and hypotheses, helping them to raise relevant questions in relation to the research focus. The working sessions were complemented by an ongoing exchange of information and communication using different means. Five multi-sited ethnographies (Falzon 2009) that moved through school and home, and virtual environments (Hine 2005), were developed by these five groups of students.

We shared with them the decision-making and the responsibility to carry out a participatory and ethnographic learning process (McCartan, Schubotz, and Murphy 2012). They wrote their own texts, brought their own images and even elaborated their own conclusions, guided by us when they asked for support. Therefore, the collected data resulted into five collaborative ethnographic narratives developed by each group of students, plus the five reports drawn up by research team building on the data collected by them through the whole research process (Table 2). During this period, we took field notes, photos, and videos, did observations and raised conversations, both with students and teachers. These sources were converted into field diaries. These diaries, the insights coming from our research meetings, and the youth ethnographic accounts, were the bases to write five interpretative ethnographic reports (Denzin 1997).

Table 2. Research process synthesis.

\begin{tabular}{|c|c|c|c|c|c|}
\hline Schools & $\begin{array}{c}\text { No of } \\
\text { students }\end{array}$ & $\begin{array}{c}\text { No of } \\
\text { university } \\
\text { researchers }\end{array}$ & $\begin{array}{l}\text { Number of } \\
\text { ethnographic } \\
\text { narratives }\end{array}$ & Collaboration tools & $\begin{array}{l}\text { Data collection } \\
\text { methods }\end{array}$ \\
\hline $\begin{array}{ll}\text { - } & \text { Els Alfacs } \\
\text { - } & \text { El Palau } \\
\text { - } & \text { Riera Baixa } \\
\text { - } & \text { La Mallola } \\
\text { - } & \text { Virola }\end{array}$ & 34 & 10 & $\begin{array}{c}10 \\
5 \text { by students } \\
5 \text { by researchers }\end{array}$ & $\begin{array}{l}\text { - Methodologies and practices } \\
\text { of collaborative work } \\
\text { Variety of digital resources: } \\
\text { (i) Virtual learning environment } \\
\text { (ii) E-mail } \\
\text { (iii) Services of social networks } \\
\text { (iv) Shared and collaborative } \\
\text { online documents } \\
\text { (v) Intranet or web and } \\
\text { Internet service }\end{array}$ & $\begin{array}{l}\text { - Observation } \\
\text { - } \text { Field dairies } \\
\text { - } \text { Interviews } \\
\text { - Visual methods (photos, } \\
\text { videos, image elicitation } \\
\text { - Teaching materials } \\
\text { analysis }\end{array}$ \\
\hline
\end{tabular}


The questions underlying these reports were: How learning experiences inside and outside school are related through youth social practices and their personal and cultural agendas? How do these experiences affect secondary school learning structures in relation to students' engagement, diversity, and the use of digital technology and multi-literacy practices?

Our reports contained ethnographic evidence themed according to categories identified prior to and during the development of the fieldwork. The collaborative analysis was carried out by the research team, as part of an ongoing process of writing and reflection. This analytical process embraced post-structural ethnographers' claims for a new ontological understanding of the relationship between data and interpretation (Mazzei and Jackson 2012).The questions underlying these reports were: How learning experiences inside and outside school are related through youth social practices and their personal and cultural agendas? How do these experiences affect secondary school learning structures in relation to students' engagement, diversity, and the use of digital technology and multi-literacy practices?

\section{From ethnographic reports to meta-ethnography}

After writing our interpretative reports, we discussed the necessity of putting them in conversation. In part, it was coherent with the purpose of generating knowledge about the similarities and singularities among the cases. Also because, after our participation at the ECER2014 Symposium: The Potentials and Challenges of Synthesizing Data in Ethnographical studies in Education, we realised that the uniqueness of an ethnographic study was compatible with its relation to other studies that have addressed similar issues and problems.

These challenges brought us to explore the epistemological and methodological foundations of meta-ethnographical analysis (Beach 2010; Beach et al. 2013; Doyle 2003; Hammersely 2010,2013; Tuquero 2011), as well as to design a strategy to find similarities and differences among our ethnographic accounts. All with the aim of deepening and going beyond the narratives to find insights on youth learning transitions in and outside secondary school. We completed this process with the readings and practices on the second generation of grounded theory (Charmaz 2006; Clarke 2005; Tavory and Timmermans 2009) content, thematic analysis (Fereday and Muir-Cochrane 2006) and coding (Saldaña 2013) which provided us with a conceptual frame and methods to code, conceptualise, categorise, theming, and interpret the ethnographic reports.

Demonstrating what the five cases have in common does not necessarily mean they are the tokens of a general type/category. Ragin's method allows to extract commonalities across the material while maintaining the individuality of each case. This is achieved by working with qualitative differences.

... This qualitative difference captures the essence of viewing cases as configurations: Two cases may be similar in most ways but because they differ on one or more key aspects, their difference may be one of kind, not simply of degree. (Ragin 2000, 71)

In our context, although similarities may be observed across the five cases, differences are not understood as of deviations from the norm but as possibly harbouring a qualitative distinction. The comparison between the five ethnographic reports therefore does not 
aim to flesh out the smallest common denominator but rather to expose the inherent diversity. It aims to arrive at a space of possibilities that charts the decisive actors that configure youth learning experiences. Similarities and differences between the cases thus equally contribute to establish what Ragin $(2000,76)$ calls a 'property space' of young people learning transitions.

In sum, a diversity-oriented comparative approach across the five reports would mean to establish first the decisive dimensions to be found across all cases. Second, it would allow evaluating the variation across the cases in terms of secondary school contexts and researchers approach, in order to detect qualitative differences. Thus, as the result of our comparison, does not interfere with the contextual process that constituted each case in question. It remains sensitive to the small, qualitative differences that are essential for understanding each singular case (Müller et al. 2007).

\section{The meta-ethnographic analysis}

After discussing the pros and cons of doing ethnography comparison, we explored different possibilities of using interpretative synthesis methods to analyse and contrast ethnographic cases (Beach et al. 2014; Weed 2005). Finally, the method we used for developing the comparative meta-ethnography was inspired both by grounded theory procedures (Willig 2001), such as living coding, categorisation, conceptualisation, thematisation and analytical memos, and an adaptation of Beach et al. (2014) five steps for a meta-ethnographic research. By crossing these two approaches, we initially decided to take the following steps:

(1) Reading carefully and collaboratively our five interpretative ethnographic reports to catch, by using a living codification procedure, the emerging key concepts, related to the research questions.

(2) Selecting all the fragments of each report related to each key concept.

(3) Analysing in pairs each report to check and validate the relevance of each key concept for each of the narratives as a foundation for making general claims and qualitative differences.

(4) Challenging and supporting these claims with ethnographic evidence.

(5) Making key comparisons with findings and discussions with cutting-edge literature.

\section{The 'real' process of meta-analysis}

When we went into the accounts we realised the meta-analysis process was more complex than we initially expected, resulting finally into 11 interwoven steps.

(1) Two members of the research team, who have not been part of in the specific ethnographic case, made a careful reading of the text, with the aim of finding a set of concepts that, as categories, could help later to organise the comparison. These categories, as key notions, were connected with the research's objectives and, at the same time, with each case context and circumstances.

(2) In an open coding process, the same two researchers, highlighted conclusive excerpts from the texts that represented actions, declarations or thoughts related to the focus 
of the research project. As Strauss and Corbin (1990) pointed out, we considered open coding as the part of the analysis concerned with identifying, naming, categorising and describing phenomena found in the text in search of the answer to the question 'what is this about? What is being referenced here?'

(3) After two researchers performing open coding on each text, the research team reviewed, in a collaborative manner, the inductive results to contrast and analyse the similarities and differences represented in each analysis.

(4) The research team used data emerging from the open coding and agreed on five common categories emerging from the five ethnographies: learning, diversity (of students), context, literacies, and engagement (Table 3).

(5) In a second reading, we revised the texts and used these five categories to guide our coding. This new reading produced codes that provide more complexity and nuances to the original categories; each category had a high number of corresponding codes.

(6) After this analytic coding, we reviewed the codes as a research team. This process revealed both the similarities across cases and highlighted the particularities of each case.

(7) Because of the comparison of the codes generated from each text, and the debate among all the researchers, an analytic coding list was generated. Maintaining the categories defined in step 4, as can be seen in Table 3, we unified the different codes through a collaborative process (Saldaña 2013).

(8) We then performed a third reading, again working in pairs. The sentences we highlighted in step 2 were classified according to this new common coding system. In this process, we assumed that each excerpt could be classified in more than one subcategory.

(9) As a result of this new coding process, the five ethnographic accounts were organised and compared based on the five categories. We grouped the excerpts from each text according to the subcategories.

Table 3. Categories emerging from the five ethnographies.

Categories

305

\section{Students diversity}

1.1. Pedagogical relations (learning subjects: students, teachers, researchers; everything that affects the relationships between subjects, who occupy different positions, or peers to establish vertical or horizontal relationships) ...

1.2. Learning environments and time: in and out

1.3. Learning conditions. All that facilitates or inhibits learning: ethos, challenging issues, ability to succeed, social relations, positive inputs, developmentally appropriate feedback ...

1.4. Learning strategies. What is done to promote learning motivation, group learning, learning tools...

2.1. For schools/teachers

2.2. For the research

2.3. For young people

3. Context 3.1. Inside school (independent of the research process)

3.2. In the relation between the school and the University

3.3.Outside school

4. Literacies 4.1. Languages and modes of communication

4.2. Use of digital technologies

4.3. Multi-literacies

5. Young people 5.1. In the research

engagement $\quad 5.2$. In school

5.3. Conditions for engagement 
(10) The sub-coding groupings led us to compare the five reports developing an in-depth analysis for each of the five main categories. This analysis allowed to make comparisons among the cases, and to emerge similarities and differences, as well to synthesise the main finding in and across the five ethnographic accounts.

(11) Finally, these results were placed in the context of cutting-edge literature referred to the experiences of young when they learn in and outside secondary schools.

In front of the impossibility of exploring the five key categories and subcategories in the scope of this paper, we show a comparative ethnography synthesis around the subcategory 1.2. Environments and time: in and out.

\section{Comparing the experiences of learning in five ethnographic reports}

Learning is, without doubts, one of the key notions in education, in social and economic arenas and especially in our research project. The idea that a new approach to learning is necessary in a 'world of constant change' (Thomas and Brown 2011), particularly as consequence of living in a digital era (Sharpe, Beethan, and de Freitas 2010), entails that an 'effective education can no longer be focused on transmission of pieces of information, that, once memorized constitute a stable storehouse of knowledge' (Darling-Hammon 2008, 2).

These are the reasons to concentrate our comparative meta-analysis in the category of 'learning', and more specifically in the subcategory 1.2. Learning environments and time: inside and outside school and its related themes (Table 4).

This subcategory links with the main aim of the research project: youth experiences of learning inside and outside secondary schools. This means comparing, on the one hand, how young people talk about their transitions between these two scenarios, and the value given by them to their learning experiences. On the other hand, it allows paying attention to the conditions of these learning experiences. This gives the opportunity to compare the themes placed under this subcategory.

\section{What the meta-ethnography makes visible about students' learning transitions in and out secondary schools}

As we mentioned above our first hypothesis was that there is a gap between what schools consider as learning and how young people learn outside school when they build communities with colleagues and use new literacies. This premise was based on the impressive development of digital technologies (Wong, Milrad, and Specht 2015) that has increased the interest and need of paying attention not only to what goes on inside and outside school (Bennett, Maton, and Kervin 2008; Skinner et al. 2008; Tan 2010). We also sought students perspectives and visions as a possible alternative to the challenges faced by education (Fielding 2001, 2010; Hadfield and Haw 2001; Riley and Docking 2004; Singala and Swanna 2011), in particular the growing disengagement and disaffection among students (Linnakyläa and Malina 2008).

In fact, in the selected subcategory for the comparative analysis (1.2) we found that the only theme with entries in all interpretative ethnographic accounts was Connecting in and outside learning, the most relevant for our study. 
Table 4. Themes around the category of learning.

\begin{tabular}{|c|c|c|c|}
\hline \multicolumn{4}{|c|}{ 1. Learning } \\
\hline $\begin{array}{l}\text { 1.1. Pedagogical } \\
\text { relations }\end{array}$ & $\begin{array}{l}\text { 1.2. Learning environments } \\
\text { and time: inside and outside } \\
\text { school }\end{array}$ & 1.3. Learning conditions & 1.4. Learning strategies \\
\hline Themes & Themes & Themes & Themes \\
\hline $\begin{array}{l}\text { - Respectful attitude } \\
\text { towards students' } \\
\text { perspectives } \\
\text { - Horizontal } \\
\text { relationships } \\
\text { - } \text { Researchers } \\
\text { expectations } \\
\text { - Trust relationship } \\
\text { - Teachers' attitude to } \\
\text { the research project }\end{array}$ & $\begin{array}{l}\text { - Connecting in and outside } \\
\text { learning } \\
\text { The school organisation: } \\
\text { the use and distribution of } \\
\text { time and spaces } \\
\text { Teachers versus students' } \\
\text { roles and expectations } \\
\text { about learning } \\
\text { Diversity of learning } \\
\text { contexts (learning } \\
\text { everywhere) } \\
\text { Perception of time during } \\
\text { the research } \\
\text { Compromise with the } \\
\text { institution }\end{array}$ & $\begin{array}{l}\text { - Expectations/(dis)trust in } \\
\text { school learning } \\
\text { - Self-regulated learning } \\
\text { (out) } \\
\text { - The interest of the tutor } \\
\text { for students } \\
\text { development in the } \\
\text { Project } \\
\text { - The need and difficulty of } \\
\text { breaking school routines } \\
\text { - The need of frames } \\
\text { - The organisation of } \\
\text { youth groups by 'levels' } \\
\text { - Symbolic dimensions of } \\
\text { space }\end{array}$ & $\begin{array}{l}\text { - Starting learning from } \\
\text { their own experiences } \\
\text { - The importance of } \\
\text { collecting evidences of the } \\
\text { learning process } \\
\text { - Learning research } \\
\text { methods } \\
\text { - The importance of sizing } \\
\text { up the learning process } \\
\text { - Learning in group/co- } \\
\text { teaching } \\
\text { - Communication strategies } \\
\text { - Visual aids } \\
\text { - Turiosity } \\
\text { - Teaching/research aids } \\
\text { (beyond information) } \\
\text { - Nearning tools } \\
\text { - The learning approaches } \\
\text { Theyond description }\end{array}$ \\
\hline
\end{tabular}

In the analysed interpretative ethnographic accounts are fundamentally two voices: from the students and the researchers. The scholars are who wrote the analysed ethnographies, as authors like Geertz (1989) point out, reflect their concerns, prejudgements, and wishes. In some occasions, they speak in the name of the youth. Nevertheless, students are permanently in the text, with their names, quotations, and stories.

\section{Similarities with nuances}

All the narratives talk about the students' learning transitions between inside and outside the school. Nonetheless, these movements do not receive a homogenous interpretation. For some students everything seems rather connected and do not establish a sharp line between their inside and outside learning experiences. They seem to find more ways for taking into account school knowledge to give meaning of the surrounding world than schools for providing a more embodied and experiential learning. However, among students there are variations and disparities.

(1) Everything is connected:

From the first session the youth expressed that, there is a relationship between the inside and the outside, which are not separate worlds. Massiel was the one that made this idea explicit. Thus, in explaining her graphical representation on the IN-OUT, she spoke of her interests, things she liked in and out of school, mixing everything, because according to her, there is no gap between the IN and OUT. (IES El Palau)

(2) Two connected contexts, without specification of the meaning of these links: 
Two realities that are not dichotomous, but cross and feedback as a transit areas. (Escola Virolai)

(3) Two linked milieus around some topics, tools or strategies:

Outside of school, we go on working on concepts we learned in through homework and expand our knowledge as many times as we use technology to provide more information. (IES Ribera Baixa)

(4) Two complementary or intersectional spaces:

We could see how she made a great effort to collect her thoughts and express the relationship between the inside and the outside through a metaphor: two wedding rings. They are meaningless if they are separated, and the two spaces neither have meaning if they are apart. They must feed each other in a symbiotic relationship. (IES Els Alfacs)

The inside, or the school, could be considered rather as a subcategory of the outside, breaking the binary vision with which we began the research. (IES La Mallola)

(5) Internet contributes to promote these connections:

OUT entered in IN through social networks that cannot be controlled by the institution. (IES Palau)

(6) The two environments, for students, could be much more complementary, with more eager and attentive teachers, ready to understand and deal with the complexities of the world:

To improve the relationship, it is necessary that both the outside and the inside want this symbiosis to happen. Therefore, teachers should want to have a relationship with the outside. (IES Els Alfacs)

(7) Because there is a perceived dichotomy linked to different issues such as the inability of school to take into account students learning experience out of school, that often are more meaningful for them:

What they learn in somehow helps them to understand the outside world, but what they learn outside is not usually incorporated and taken into account at school. Only in a very few classes teachers pay attention to their experience, knowledge and understandings. At school they learn things to pass exams, but once passed they find difficult to remember them. They tend to remember what they learn outside, because for them this learning is more meaningful, is more related to their experiences, interests, and social and emotional relationships. Although digital technology is increasingly incorporate in classes, it is used differently inside and outside school. Within often its use places them as spectators and recipients of information, outside its use increases their responsibility, agency, ability to scan information, to communicate and express. (IES Ribera Baixa)

(8) Even a consideration of the school experience as little more than an obligation:

I learn little in school. I spend most of my time looking for information ... I look for things not explained at school in Internet... [... In the class, I listen, but not too much, because just being attentive you get the picture. And with the computers, everything is fatal ... there are always [problems] ... And I know too much. I learned to produce videos, movies, songs ... The camera ... I know a lot about videos: effects, how to assemble a video, and so on. (IES Els Alfacs)

(9) That dichotomy becomes part of the discussion when the students refer to the priorities for their life futures: 
Nuria introduces the concept of 'experience' as associated to learning. For her, there are things you learn IN that are not valuable for the future, while other things you learn OUT are helping for the future. (La Mallola)

Marta highly valued learning at the secondary school, because it had to do with her future. [ ... ] For her, lessons were first: 'basic and key.' While outside, in the real life: 'secondary and essential,' was where it was put into practice o demonstrated what it had been learned. (IES Els Alfacs)

(10) Or to the gap generated by their relations with the school rules:

In the IN we learn on matters imposed on us, not elected, and in the OUT we learn by our own experience. (IES Palau)

The rules in school are different from the rules outside. The school rules help you to be a right person, while the rules out help you to be a civil person (work group A). (IES Palau)

(11) On the other hand, the perception on their learning movements changed along the research. At the beginning, most of them reinforced the idea of the dichotomy:

From the observations that young people performed in classes, emerged the idea that in the IN, learning is traditional, largely unidirectional and focused on listening to the teacher. This seems as opposed to learning OUT, based on two-ways communication in and sharing information and experiences related to their interests: 'Through Facebook we have seen that each person learns from his/her different interests and the relationships with his/her friends'. (IES Palau)

(12) While, at the end of the journey, they have learnt to perceive relations and continuities:

Paul: '[I learned] to see that in the school and outside there is not much difference as initially thought' and Massiel: 'Now I know that the things we do and learn in, have a lot to do with things we do and learn outside.' (IES Palau)

From our side, as researchers, what we found is that, 'when the concept of learning shifts from the school context - when we speak of savoir (Charlot 2000) rather than information or knowledge - we quickly lose our capacity to define it' (IES La Mallola).

What this comparative analysis of the five interpretative ethnographic accounts reveals is that learning in general, both in and outside secondary school is, over all, a 'performatic gesture' (Fendler 2015) which is possible capture theoretically within the notion of 'learning mobilities' (Enriquez 2009; Landri and Neumann 2013). Mobilities considered as an area of inquiry, which refocus our approach to learning, positioning it not as a scholastic objective subject to assessment but rather as a multi-located and process-oriented experience.

Focusing on the multi-sited and mobile aspect of learning, our ethnographic approach seems to represent the complexity of young people's ways of learning. To explain this complexity, Leander, Phillips, and Headrick Taylor (2010) propose three 'expansive metaphors' for 'the study of learning in space-time' (330): learning-in-place, learning trajectories, and learning networks. Arguing against 'historically sedimented geography within education research' (Leander, Phillips, and Headrick Taylor 2010), their review of learning mobilities methodologically reveals that learning is not a fixed phenomenon but is produced across varied contexts and within a range of social practices. 
Institutional pedagogy, by the contrary, has a narrower understanding of learning, which tends to be prescriptive, curriculum-based and teacher-oriented. Our project, therefore, disrupted young people's established relationship with school as we invited them, as we see in the comparative account, to reflect critically on the role of learning in their lives.

\section{Concluding remarks on the youth learning ethnographies and its meta- analysis}

Taking into account the four questions proposed by this monograph's editors, in this final part we will discuss two issues. First, some of the aspects of young people learning process that have emerged from the meta-analysis and relate to the aim of the research: understanding the conditions in which young people learn inside and outside school and how these conditions have an effect in the constitution of their learning subjectivities. Second, our learning about the possibilities and limitations of the meta-ethnographic analysis, based on the experience presented in this paper.

Regarding the comparative meta-ethnographic analysis, our findings run in two directions. We have been able to (a) review the capabilities and limitations (those coming from these invisible, but relevant, aspects of the research problem) of the meta-ethnographic analysis; and (b) discuss the findings about youth/earning representations and experiences emerging from the three main layers of analysis. This is to say: (i) students learning transitions and mobilities that emerge from developing an ethnographic research on their own learning experiences; (ii) researchers' ethnographic accounts on students learning processes; and (iii) the contextualisation of these two positionalities in each institutional context.

In contrast to some of the literature on young people's learning (Eshach 2007; Menten 2011; Quigley 2014, among others) our analysis points out that, although young people perceive they learn differently in different environments, there are connections among them. These links are conceptualised in terms of transitions and learning mobilities on the use and appropriation of learning strategies generated inside and outside school. In their ethnographic accounts young people showed us that they were learning every minute and everywhere; that learning was 'happening all around us, everywhere, and it is powerful' (La Mallola).

They recognise that ways of learning generated in different environments are mutually influenced; however they also think schools and teachers do not take into account the possibilities of these interrelations, and they do not consider and integrate in their teaching the learning modes and the use of digital tools coming from outside school.

This study makes also a significant contribution to the emerging need in Social Sciences of recognising people's agency by including them, as authors, in the research process (Nind 2014). This happened in our case by doing research with and not on people; and making sure the research process and results are significant not only for researchers and the academic community, but also, and in the first place, for those involved in the studied phenomena.

The five ethnographic studies undertaken by students plus the five ethnographies conducted by researchers giving account of this process have produced significant results regarding the comprehension of how, with what, and with whom students communicate, express themselves, and learn inside and outside school. We refer, for example, to the 
change of attitudes and the increasing involvement, when students authorised themselves to speak, discuss, question, and how they improved their forms of expression and communication. From the perspective of educational research, this represents a process that educates all the participants, for us this constitutes the most important result.

During the meta-ethnographic analytical development, taking into account post-structural ethnographers' (Lather 1993; Mazzei and Jackson 2012; St. Pierre and Pillow 2000) claims for a new ontological understanding of the relationship between data and interpretation, we realised the constrains of the process itself. In our case, we recognised, for instance, that grounded theory was not sufficiently mobile for grounding the analysis our meta-analysis. Mainly, because, the fieldwork, the writing of the reports, and the meta-ethnographic comparison evidenced that reflecting on youth learning experiences is not a straightforward task. Learning, as Fendler (2015) emphasises, is a slippery term, and quickly loses specificity when removed from school goals and sees its complexity reduced by a coding framework.

Because we could not approach learning directly, our research did not follow a linear path, but instead seemed to spiral outward. Through dialogue, multiple meanings evolved that added resonance to the understanding of the role and presence of learning in youth and researchers' lives. We, as researchers, recognise that the learning process that takes place during the research is essential to represent and understand youth learning mobilities. However, it is no easy to give account of these processes through a narrative form. Even more difficult is to capture that meaning through a meta-ethnography, where different modes of presenting the hidden learning experiences needed to be placed in comparison. The aim of the meta-analysis became to work towards an ethnographic account that engendered a language of possibility rather than a language of certitude. This is not an aesthetic decision, but an attempt at better representing the object of the meta-ethnography: how to characterise the variety of youth' learning experiences in their mobilities and transitions in and outside schools and the ways of giving account of them in five ethnographic reports.

By locating learning within a smooth space, a space of affect and intensities that cannot be measured and represented by external standards or its internal forms, we recognise that it contains activities that escape classification and coding strategies of analysis. This issue is articulated by Atkinson $(2011,13)$, when pointing out that

within teaching and learning contexts it is quite possible for there to be learners whose ontological status of learners is not recognized so their potential for becoming is constrained and therefore they have no (or marginal) existence within the pedagogical space.

By confronting ourselves with the possibilities and limitations of a meta-ethnographic analysis, our research attempts, not only to intervene in and expand our social imaginary of learning, but contributing from the ethnographic research to explore and develop the complexities of youth learning in the contemporary society.

\section{Notes}

1. IN-OUT - Living and learning with new literacies in and outside secondary school: contributions to reducing drop-out, exclusion and disaffection among youth (MINECO. EDU2011-24122).

2. Source: Labour Force Survey-Eurostat 2013.

3. http://esbrina.eu/docs/invitacio_trobada_in-out.pdf. 


\section{Disclosure statement}

No potential conflict of interest was reported by the authors.

\section{Funding}

This work has been financially supported by The Spanish Minister of Economy and Competitiveness [grant EDU2011-24122].

ORCID

Jud P. Sancho-Gil (D) http://orcid.org/0000-0002-2941-5619

\section{References}

Anderson, G. L., and K. Herr. 1994. "The Micro Politics of Student Voices: Moving from Diversity of Bodies to Diversity of Voices in Schools." In The new Politics of Race and Gender, edited by Catherine Marshall, 58-68. London: Routledge-Falmer.

Atkinson, D. 2011. Art, Quality and Learning. Pedagogies Against the State. Rotterdam: Sense.

Beach, D. 2010. "Identifying Scandinavian Ethnography: Comparisons and Influences." Ethnography and Education 5: 1-19.

Beach, D., C. Bagley, A. Eriksson, and C. Player-Koro. 2014. "Changing Teacher Education in Sweden: Using Meta-ethnographic Analysis to Understand and Describe Policy Making and Educational Changes." Teaching and Teacher Education 44: 160-167.

Beach, D., M. Dovemark, A. Schwartz, and E. Öhrn. 2013. "Complexities and Contradictions of Educational Inclusion: A Meta-ethnographical Analysis." Nordic Studies in Education 33: 254268.

Bennett, S., K. Maton, and L. Kervin. 2008. "The 'Digital Natives' Debate: A Critical Review of the Evidence." British Journal of Educational Technology 39 (5): 775-786. doi:10.1111/j.1467-8535. 2007.00793.

Charlot, B. 2000. "Le rapport au savoir en milieu populaire: 'aprendre à l'école' et " aprendre la vei" [The Report of Knowledge in the Popular Milieu: "Learning in School" and "Learning in Life"]. VEI Enjeux 123: 56-63.

Charmaz, K. 2006. Constructing Grounded Theory: A Practical Guide Through Qualitative Analysis. London: Sage.

Clarke, A. E. 2005. Situational Analysis: Grounded Theory after the Postmodern Turn. Thousand Oaks, CA: Sage.

620 Darling-Hammon, L. 2008. Powerful Learning: What We Know about Teaching for Understanding. San Francisco, CA: Josey Bass.

Denzin, N. K. 1997. Interpretive Ethnography: Ethnographic Practices for the 21st Century. Thousand Oaks, CA: Sage.

Departament D’Educació. 2010. Currículum d'Educació Secundària Obligatòria [Curriculum of Compulsory Secondary Education]. Barcelona: Departament d'Educació.

Doyle, L. H. 2003. "Synthesis through Meta-ethnography: Paradoxes, Enhancements, and Possibilities." Qualitative Research 3: 321-344.

Enriquez, J. G. 2009. “Tug-o-where: Practising Mobilities of Learning (T)here.” In Same Places, Different Spaces. Proceedings Ascilite Auckland 2009, 273-284. Accessed May 2012. http:// www.ascilite.org.au/conferences/auckland09/procs/enriquez.pdf.

Eshach, H. 2007. "Bridging In-School and Out-of-School Learning: Formal, Non-formal, and Informal Education.” Journal of Science Education and Technology 16 (2): 171-190. doi:10. 1007/s10956-006-9027-1. 
Falzon, M-A. 2009. "Introduction. Multi-sited Ethnography: Theory, Praxis and Locality in Contemporary Research." In Multi-sited Ethnography: Theory, Praxis and Locality in Contemporary Research, edited by Mark-Anthony Falzon, 1-23. Farnham: Ashgate.

Fendler, R. 2015. "Tracing the Eventful Space of Learning: In and Out of a Collaborative Ethnography with Youth.” Paper Presented at the annual meeting of AERA, Chicago, April 16-20.

Fereday, J., and E. Muir-Cochrane. 2006. "Demonstrating Rigor Using Thematic Analysis: A Hybrid Approach of Inductive and Deductive Coding and Theme Development." International Journal of Qualitative Methods 5 (1), Article xx. Accessed December 2014. http://www.ualberta.ca/ iiqm/backissues/5_1/pdf/fereday.pdf.

Fielding, M. 2001. "Students as Radical Agents of Change." Journal of Educational Change 2 (2): 123-141.

Fielding, M. 2010. "The Radical Potential of Student Voice: Creating Spaces for Restless Encounters." The International Journal of Emotional Education 2 (1): 61-73.

Geertz, C. 1989. Work and Lives: The Anthropologist as Author. Stanford, CA: Stanford University Press.

Hadfield, M., and K. Haw. 2001. "'Voice', Young People and Action Research.” Educational Action Research 9 (3): 485-502. doi:10.1080/09650790100200165.

Hammersely, M. 2010. "Can We Re-use Qualitative Data Via Secondary Analysis? Notes on Some Terminological and Substantive Issues.” Sociological Research Online 15 (1): 15. doi:10.5153/sro. 2076.

Hammersley, M. 2013. "What Is Qualitative Synthesis and why do it?" In The Myth of Research Based Policy and Practice, edited by Martyn Hammersley, 130-151. London: Sage.

Heath, S., R. Brooks, E. Cleaver, and E. Ireland. 2009. Researching Young People's Lives. London: Sage.

Hernández, F. 2011. Investigar con los jóvenes: cuestiones temáticas, metodológicas, éticas y educativas [Researching with Young People: Thematic, Methodological, Ethical and Educational Issues]. Barcelona: Depósito digital de la UB. http://diposit.ub.edu/dspace/handle/2445/17362.

Hine, C. 2000. Virtual Ethnography. London: Sage.

Hine, C. 2005. Virtual Methods. Issues in Social Research on the Internet. Oxford: Berg.

Jhons, M., S. C. Shin-Ling, and G. J. Hall. 2004. Online Social Research: Methods, Issues, and Ethics. New York: Peter Lang.

Landri, P., and E. Neumann. 2013. "Introduction: Mobile Sociologies of Education." European Educational Research Journal 13 (1): 1-8.

Leander, K. M. N. C. Phillips, and K. Headrick Taylor. 2010. "The Changing Social Spaces of Learning: Mapping New Mobilities.” Review of Research in Education 34: 329-394.

Linnakyläa, P., and A. Malina. 2008. "Finnish Students" School Engagement Profiles in the Light of PISA 2003.” Scandinavian Journal of Educational Research 52 (6): 583-602. doi:10.1080/ 00313830802497174.

Marcus, G. E. 1995. "Ethnography in/of the World System: The Emergence of Multi-sited Ethnography.” Annual Review of Anthropology 24: 95-117.

Mazzei, L. A., and A. Y. Jackson. 2012. "Complicating Voice in a Refusal to 'Let Participants Speak for Themselves'.” Qualitative Inquiry 18 (9): 745-751.

McCartan, C., D. Schubotz, and J. Murphy. 2012. "The Self-conscious Researcher - Post-modern Perspectives of Participatory Research with Young People." Forum Qualitative Social Research, 13 (1). Art. 9. http://www.qualitative-research.net/index.php/fqs/article/view/1798.

Menten, A. 2011. "Expanding Horizons Through Global Learning in Out-of-School Time." New Directions for Youth Development (S1): 29-37. doi:10.1002/yd.417.

Mlodinow, L. 2012. Subliminal: How Your Unconscious Mind Rules Your Behavior. New York: Vintage books.

Müller, J., F. Hernández, J. M. Sancho, A. Creus, M. Muntadas, V. Larrain, and Xavier Giro. 2007. European School-Teachers Work and Life under Restructuring: Professional Experiences, Knowledge and Expertise in Changing Context. Professional Knowledge in Education and Health. Restructuring Work and Life Between the State and Citizens in Europe. Report No 
4. Accessed June 2008. http://www.externarelationer.adm.gu.se/digitalAssets/1321/1321781_ profknow_wp4.pdf.

Nind, M. 2014. What Is Inclusive Research? London: Bloomsbury.

Quigley, C. 2014. "Expanding Our View of Authentic Learning: Bridging in and Out-of-School Experiences." Cultural Studies of Science Education 9: 115-112.

Ragin, C. C. 1989. The Comparative Method: Moving Beyond Qualitative and Quantitative Strategies. Berkeley: University of California Press.

Ragin, C. C. 2000. Fuzz-Set Social Sciences. Chicago, IL: University of Chicago Press. Accessed June 2001. http://dx.doi.org/10.2304/eerj.2014.13.1.1.

Riley, K., and J. Docking. 2004. "Voices of Disaffected Pupils: Implications for Policy and Practice." British Journal of Educational Studies 52 (2): 166-179. doi:10.1111/j.1467-8527.2004.00261.x.

Saldaña, J. 2013. The Coding Manual for Qualitative Researchers. London: Sage.

Sharpe, R., H. Beethan, and S. de Freitas. 2010. Rethinking Learning for a Digital Age: How Learners Are Shaping Their Own Experiences. New York: Routledge.

Singala, N., and M. Swanna. 2011. "Children's Perceptions of Themselves as Learner Inside and Outside School." Research Papers in Education 26 (4): 469-484. doi:10.1080/ 02671520903281617.

Skinner, E., C. Furrer, G. Marchand, and T. Kindermann. 2008. "Engagement and Disaffection in the Classroom: Part of a Larger Motivational Dynamic?" Journal of Educational Psychology 100 (4): 765-781. http://dx.doi.org/10.1037/a0012840.

Stoll, L., D. Fink, and L. Earl. 2001. It's About Learning (and It's About Time) What's in It for Schools? London: Routledge.

St. Pierre, E., and W. S. Pillow. 2000. Working the Ruins. Feminist Poststructural Theory and Methods in Education. London: Routledge.

Strauss, A., and J. Corbin. 1990. Basics of Qualitative Research: Grounded Theory. London.: Sage.

Tan, L. W. L. 2010. "Adolescent Literacies, Multimodal Textual Repertoires and Digital Media: Exploring Sites of Digital Literacy Practices and Learning, Inside and Outside School." Unpublished $\mathrm{PhD}$ diss., Lancaster University.

Tavory, I., and S. Timmermans. 2009. "Two Cases of Ethnography: Grounded Theory and the Extended Case Method." Ethnography 10 (3): 243-263.

Thomas, D., and J. S. Brown. 2011. A New Culture of Learning: Cultivating the Imagination for a World of Constant Change. Luxemburg: CreateSpace.

Troman, G., B. Jeffrey, and G. Walford. 2005. Methodological Issues and Practices in Ethnography. Studies in Educational Ethnography. Amsterdam: Elsevier JAI.

Tuquero, J. M. 2011. "A Meta-ethnographic Synthesis of Support Services in Distance Learning Programs." Yournal of Information Technology Education 10: 157-179.

Weed, M. 2005. “Meta Interpretation': A Method for the Interpretive Synthesis of Qualitative Research.” Forum: Qualitative Social Research 6 (1), Art. 37. http://www.qualitative-research. net/index.php/fqs/article/view/508/1096.

Willig, C. 2001. Grounded Theory Methodology. In Introducing Qualitative Research in Psychology. Buckingham: Open University Press.

Wong, L. H., M. Milrad, and M. Specht. 2015. Seamless Learning in the Age of Mobile Connectivity. Singapore: Springer Singapore. 